\title{
Last Glacial Maximum ice sheet dynamics in Arctic Canada inferred from young erratics perched on ancient tors
}

\author{
J.P. Briner ${ }^{\mathrm{a}, *}$, G.H. Miller ${ }^{\mathrm{a}}$, P.T. Davis ${ }^{\mathrm{b}}$, P.R. Bierman ${ }^{\mathrm{c}}$, M. Caffee ${ }^{\mathrm{d}, 1}$ \\ ${ }^{a}$ Institute of Arctic and Alpine Research and Department of Geological Sciences, University of Colorado, Boulder, CO 80309-0450, USA \\ ${ }^{\mathrm{b}}$ Department of Natural Sciences, Bentley College, Waltham, MA 02454, USA \\ ${ }^{\mathrm{c}}$ Geology Department and School of Natural Resources, University of Vermont, Burlington, VT 05405, USA \\ ${ }^{\mathrm{d}}$ Center for Accelerator Mass Spectrometry, Lawrence Livermore National Laboratory, Livermore, CA 94550, USA
}

Received 1 September 2002; accepted 25 November 2002

\begin{abstract}
A long-standing debate regarding the reconstruction of former ice sheets revolves around the use of relative weathering of landscapes, i.e., the assumption that highly weathered landscapes have not been recently glaciated. New cosmogenic isotope measurements from upland bedrock surfaces and erratics along the northeastern margin of the Laurentide Ice Sheet (LIS) shed light on this debate. ${ }^{10} \mathrm{Be}$ and ${ }^{26} \mathrm{Al}$ concentrations from three perched erratics, yielding cosmogenic exposure ages of 17-11 ka, are much lower than those measured in two unmodified, highly weathered tors upon which they lie, which yield cosmogenic exposure ages of $>60 \mathrm{ka}$. These findings suggest that non-erosive ice covered weathered upland surfaces along the northeastern margin of the LIS during the last glacial maximum. These data challenge the use of relative weathering to define the margins of Pleistocene ice sheets. The juxtaposition of non-erosive ice over upland plateaus and erosive ice in adjacent fiords requires strong gradients in basal thermal regimes, suggestive of an ice-stream mode of glaciation.
\end{abstract}

(C) 2003 Elsevier Science Ltd. All rights reserved.

\section{Introduction}

The extent, thickness, and internal ice dynamics of Pleistocene ice sheets have been the focus of much recent research, but ice sheet reconstructions remain controversial, ranging from models that depict relatively thick and stable ice (e.g., Kleman et al., 1999) to those that depict relatively thin and unstable ice (e.g., Alley and MacAyeal, 1994; Clark, 1994). Furthermore, it is uncertain how much ice existed in high-elevation interfiord regions along ice sheet margins (e.g., Brook et al., 1996; Miller et al., 2002). Geophysical modeling has been used to reconstruct former ice sheets based on ice physics and Earth rheology (e.g., Denton et al., 1981; Peltier, 1994; Hughes, 1998), but ice sheet reconstructions, derived from field-based mapping and dating of glaciated landscapes, serve as an important validation

\footnotetext{
*Corresponding author. Tel.: + 1-303-492-5075; fax: + 1-303-4926388.

E-mail address: jason.briner@colorado.edu (J.P. Briner).

${ }^{1}$ Present address: Purdue Rare Isotope Measurement Laboratory and Department of Physics, Purdue University, West Lafayette, IN 47907, USA.
}

for such modeling. One criterion widely used to define the former location of ice sheet margins is relative weathering of landscape surfaces (e.g., Boyer and Pheasant, 1974; Sugden and Watts, 1977; Ives, 1978; Sugden, 1978).

The weathering zone concept (e.g., Ives, 1978) implies that in glaciated regions, highly weathered landscapes took a long time to form and thus must have escaped recent glaciation, whereas landscapes with fresh glacial features were recently glaciated. This assumption has been incorporated into reconstructions along the entire eastern margin of the Laurentide Ice Sheet (LIS) (e.g., Boyer and Pheasant, 1974; Ives, 1978), around the Greenland Ice Sheet (e.g., Landvik, 1994), and along the western margin of the Fennoscandian Ice Sheet (e.g., Nesje and Dahl, 1990). In concert with the weathering zone concept is the "nunatak hypothesis" (e.g., Fernald, 1925; Linton, 1950; Dahl, 1955, 1966; Ives, 1966), which suggests that highly weathered mountain tops, presumably unglaciated, served as biologic refugia throughout the Quaternary.

Some have argued against the nunatak hypothesis and the weathering zone concept (e.g., Sugden, 1978; 
Denton et al., 1981; Bierman et al., 2001). Highly weathered landscapes are preserved within the limits of large Northern Hemisphere ice sheets (the Fennoscandian, e.g., Kleman, 1994; the Laurentide, e.g., Dredge, 2000; the Innuitian, e.g., Dyke, 1993). Furthermore, the existence of "perched" or "anomalous" blocks, or "pseudo-erratics" (Ives, 1975), found on many high-elevation weathered surfaces has fueled some researchers' beliefs (e.g., Sugden and Watts, 1977) that large, all-inundating ice sheets were the dominant mode of Late Pleistocene glaciation.

Landscapes in Labrador (e.g., Ives, 1978) and eastern Baffin Island (e.g., Boyer and Pheasant, 1974) have been subdivided into three distinct weathering zones. The boundaries between these elevational zones dip seaward, and thus have been interpreted as former ice limits; the lowest, freshest zone is associated with moraines and marine deposits that date to the last glaciation, whereas higher, more weathered zones with penultimate or earlier ice advances. Here, we present cosmogenic nuclide data from the Clyde region of northeastern Baffin Island (Fig. 1) for fresh erratic blocks and weathered upland surfaces upon which they are perched that require non-erosive LGM glaciation of the weathered uplands.

\section{Setting and glacial geology}

Clyde Inlet, which dissects a high (1000-1500 m asl) coast-parallel mountain range, stretching from an inland plateau $(600-700 \mathrm{~m}$ asl) to a wide coastal foreland, is one of many fiords along northeastern Baffin Island that drained the LIS (Fig. 1). In the outer part of Clyde Inlet, upland surfaces are 400-600 $\mathrm{m}$ asl. Moraines and glacially sculpted bedrock

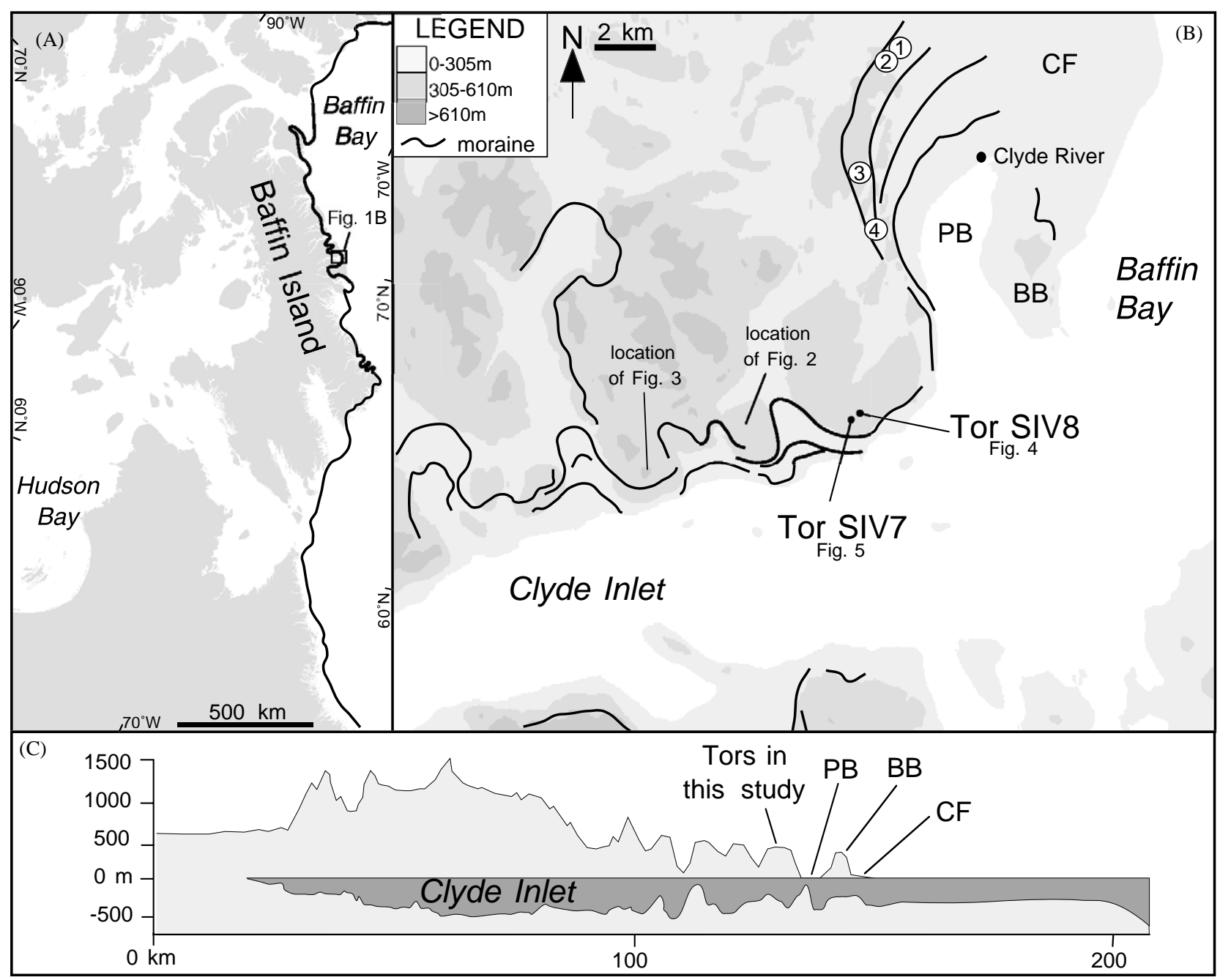

Fig. 1. (A) The eastern Canadian Arctic and the extent of the Laurentide ice sheet (indicated by solid black line) during the LGM (from Dyke et al., 2002). (B) The outer part of Clyde Inlet showing moraines (black lines) and sampled tor localities. $\mathrm{BB}=\mathrm{Black} \mathrm{Bluff}$; $\mathrm{CF}=\mathrm{Clyde}$ Foreland; $\mathrm{PB}=$ Patricia Bay. Numbered localities refer to cosmogenic exposure age sites along the outermost Patrica Bay moraines (see Table 1). Location shown in Fig. 1A. (C) Cross section of Clyde Inlet and adjacent mountains to the north. Bathymetry data for Clyde Inlet from Syvitski (unpublished data). 
characterize the lower slopes of the outer fiord walls, but at $\sim 300-500 \mathrm{~m}$ give way to upland blockfields dotted with tors.

Tors on uplands above the highest lateral moraines in outermost Clyde Inlet exhibit advanced bedrock weath- ering characteristics. The tors typically feature weathering pits (up to $30 \mathrm{~cm}$ deep and $60 \mathrm{~cm}$ in diameter; Fig. 2), grus, and quartz veins displaying $>10 \mathrm{~cm}$ of relief; vertical faces on tors reveal deep differential weathering (Fig. 3). Most summits have unweathered

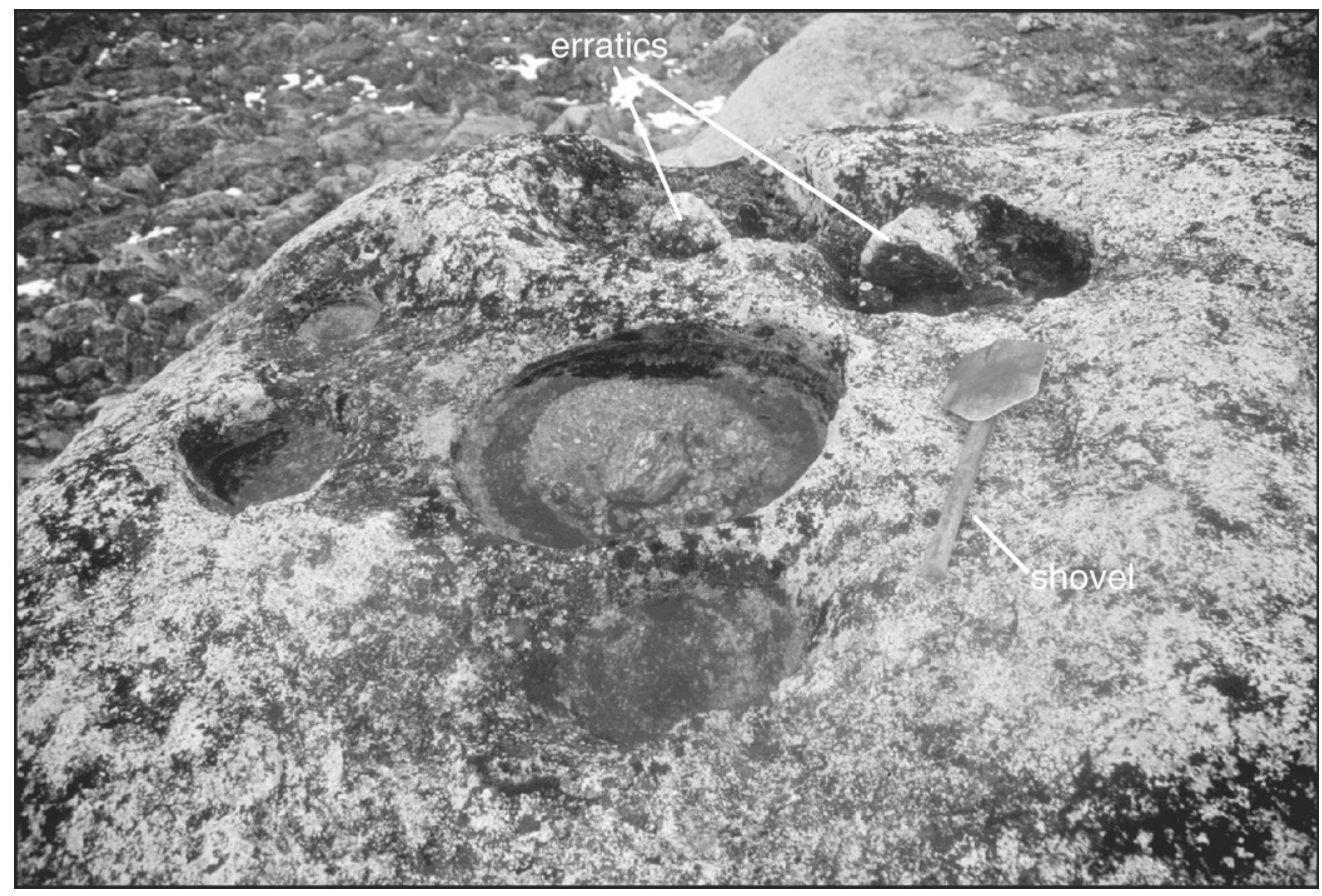

Fig. 2. Large weathering pits observed on upland bedrock surface adjacent to outer Clyde Inlet. Shovel handle is $53 \mathrm{~cm}$ long. See Fig. $1 \mathrm{~B}$ for location.

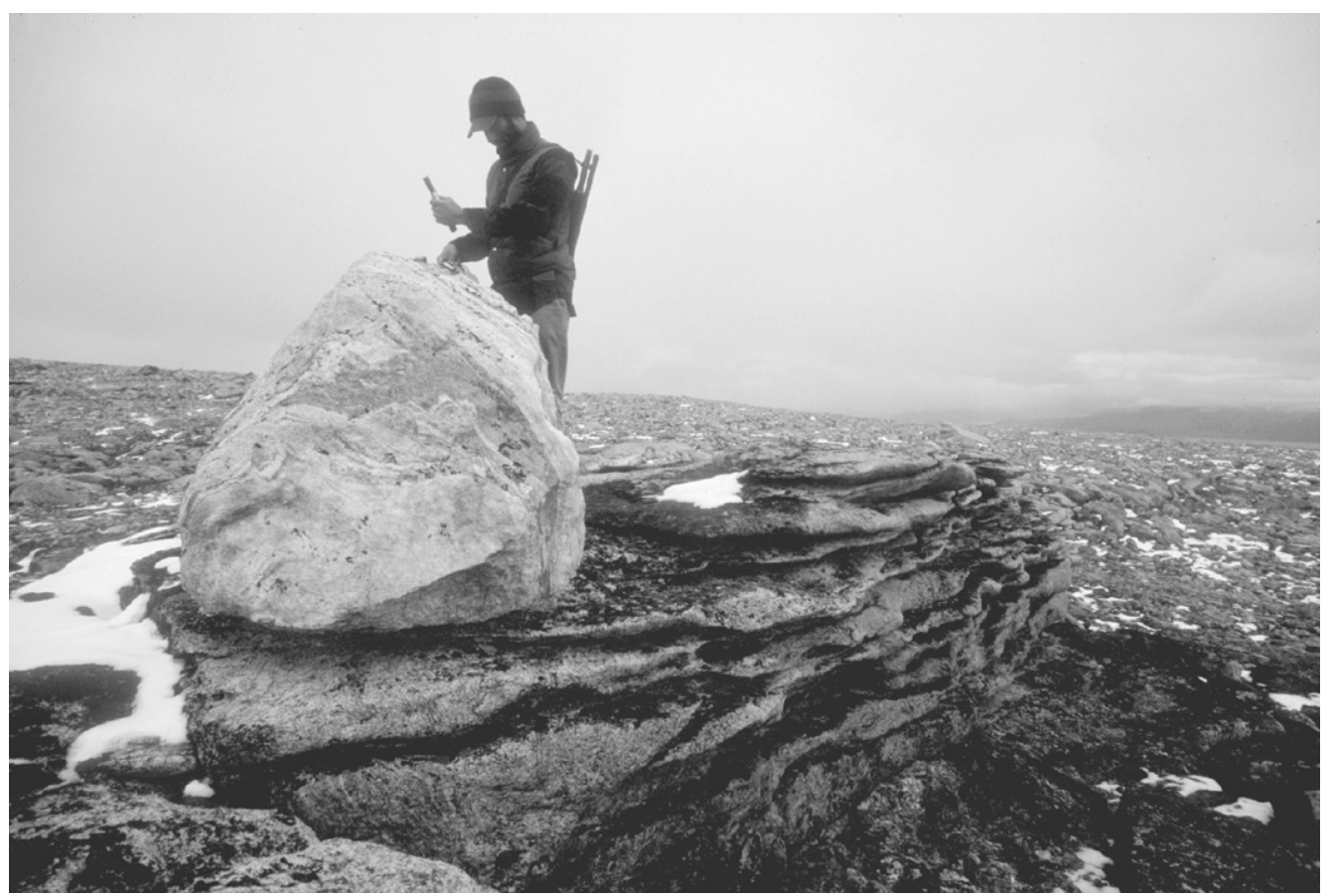

Fig. 3. Fresh erratic boulder resting directly on weathered tor. Note the intense differential weathering on the sides of the tor and the fresh appearance of the erratic. See Fig. 1B for location. 
granitic and gneissic cobbles and boulders perched atop much more weathered tors (Figs. 4 and 5). Many of the cobbles and boulders are lithologies that are at least locally erratic. In some cases, the boulders are perched on smaller erratic cobbles (Fig. 4), or lie inside weathering pits (Fig. 2).

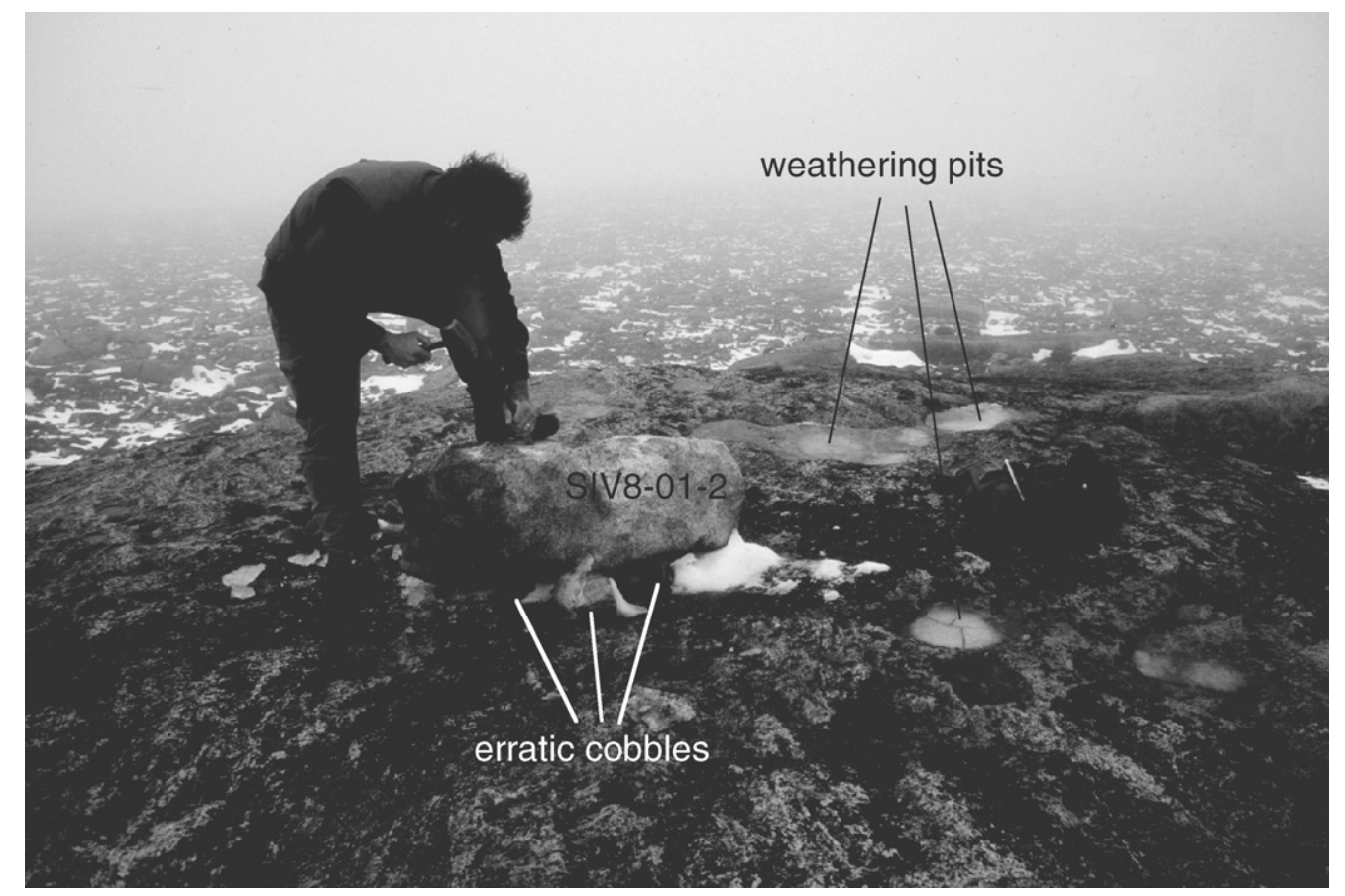

Fig. 4. Erratic boulder, perched on smaller erratic cobbles, resting on tor with well-developed weathering pits at site SIV8 (504 $\mathrm{m}$ asl). The erratic boulder (SIV8-01-2) has a cosmogenic exposure age of 16.7 $\pm 1.7 \mathrm{ka}$, and the bedrock has an age of $>67 \pm 7 \mathrm{ka}$ (SIV8-01-1). See Fig. 1B for location.

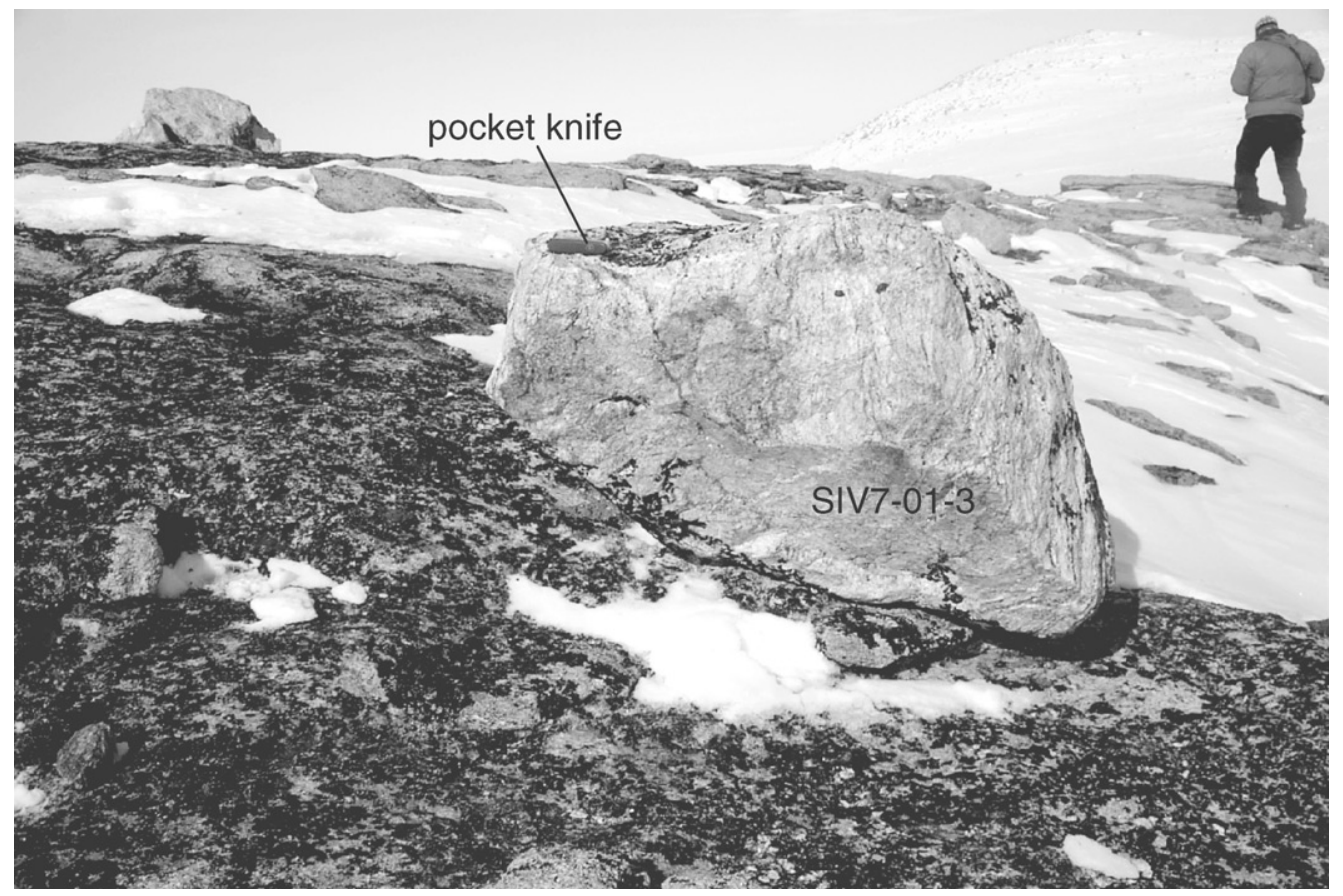

Fig. 5. Erratic boulder resting directly on tor at site SIV7 (465 m asl). The erratic boulder (SIV7-01-3) has a cosmogenic exposure age of $10.5 \pm 1.1$ ka, and the bedrock has an age of $>60 \pm 4 \mathrm{ka}$ (SIV7-00-1). See Fig. 1B for location. 
Table 1

Clyde inlet sample location information and cosmogenic exposure ages

\begin{tabular}{|c|c|c|c|c|c|c|c|c|c|}
\hline Sample & $\begin{array}{l}\text { Sample } \\
\text { type }\end{array}$ & $\begin{array}{l}\text { Lat. } \\
(\mathrm{N})\end{array}$ & $\begin{array}{l}\text { Long. } \\
\text { (W) }\end{array}$ & $\begin{array}{l}\text { Elevation } \\
\text { (m asl) }\end{array}$ & $\left.\begin{array}{l}{ }^{10} \mathrm{Be} \\
\left(10^{5} \text { atoms g }\right. \\
-1\end{array}\right)$ & $\begin{array}{l}{ }^{26} \mathrm{Al} \\
\left(10^{5} \text { atoms g }{ }^{-1}\right)\end{array}$ & $\begin{array}{l}{ }^{10} \mathrm{Be} \mathrm{age}^{\mathrm{a}} \\
(\mathrm{ka})\end{array}$ & $\begin{array}{l}{ }^{26} \mathrm{Al} \mathrm{age}{ }^{\mathrm{a}} \\
(\mathrm{ka})\end{array}$ & $\begin{array}{l}\text { Weighted mean age and } \\
1 \text { S.D. uncertainty }(\mathrm{ka})\end{array}$ \\
\hline \multicolumn{10}{|c|}{ Upland samples } \\
\hline SIV7-00-1 & Tor & $70^{\circ} 20.001^{\prime}$ & $68^{\circ} 48.044^{\prime}$ & 465 & $4.90 \pm 0.14$ & $27.02 \pm 0.77$ & $>63.1 \pm 5.6$ & $>57.3 \pm 5.9$ & $>60.3 \pm 4.1$ \\
\hline SIV7-00-2 & Cobble $^{\mathrm{b}}$ & $70^{\circ} 19.993^{\prime}$ & $68^{\circ} 48.015^{\prime}$ & 462 & $0.85 \pm 0.04$ & $6.34 \pm 0.24$ & $10.8 \pm 1.1$ & $13.2 \pm 2.1$ & $11.3 \pm 1.0$ \\
\hline SIV7-01-3 & Boulder & $70^{\circ} 20.000^{\prime}$ & $68^{\circ} 48.042^{\prime}$ & 464 & $0.81 \pm 0.03$ & $5.33 \pm 0.30$ & $10.1 \pm 1.4$ & $11.1 \pm 1.6$ & $10.5 \pm 1.1$ \\
\hline SIV8-01-1 & Tor & $70^{\circ} 20.115^{\prime}$ & $68^{\circ} 46.798^{\prime}$ & 503 & $5.54 \pm 0.17$ & $32.10 \pm 1.55$ & $>67.5 \pm 8.9$ & $>66.1 \pm 9.6$ & $>66.9 \pm 7.0$ \\
\hline SIV8-01-2 & Boulder & $70^{\circ} 20.115^{\prime}$ & $68^{\circ} 46.747^{\prime}$ & 504 & $1.46 \pm 0.06$ & $7.97 \pm 0.44$ & $17.5 \pm 2.4$ & $16.0 \pm 2.3$ & $16.7 \pm 1.7$ \\
\hline \multicolumn{10}{|c|}{ Clyde foreland samples (in order from site 1 to 4 in Fig. 1) } \\
\hline PB5-01-2 & Boulder & $70^{\circ} 30.825^{\prime}$ & $68^{\circ} 43.170^{\prime}$ & 143 & $1.06 \pm 0.10$ & - & $18.0 \pm 0.9$ & - & - \\
\hline PB5-01-1 & Boulder & $70^{\circ} 30.825^{\prime}$ & $68^{\circ} 42.997^{\prime}$ & 149 & $0.99 \pm 0.13$ & - & $16.8 \pm 1.7$ & - & - \\
\hline PB4-00-1 & Boulder & $70^{\circ} 28.168^{\prime}$ & $68^{\circ} 45.876^{\prime}$ & 215 & $1.09 \pm 0.11$ & $7.34 \pm 0.94$ & $17.9 \pm 1.2$ & $19.8 \pm 2.5$ & $18.4 \pm 1.6$ \\
\hline PB3-00-3 & Boulder & $70^{\circ} 26.993^{\prime}$ & $68^{\circ} 45.511^{\prime}$ & 192 & $1.07 \pm 0.11$ & $6.65 \pm 0.57$ & $18.0 \pm 1.2$ & $18.3 \pm 1.7$ & $18.1 \pm 1.4$ \\
\hline
\end{tabular}

${ }^{\mathrm{a}}$ Ages include AMS uncertainty (1 S.D.), and fixed uncertainties of $2 \%$ for Be carrier addition or $4 \%$ for stable $\mathrm{Al}$ measurement, $6 \%$ for production rate, and $5 \%$ for elevation scaling using $\sqrt{\sum\left(\text { error }^{2}\right)}$ (Gosse and Phillips, 2001). Ages are reported using ${ }^{10} \mathrm{Be}$ and ${ }^{26} \mathrm{Al}$ production rates of 5.1 and 31.1 atoms $\mathrm{g}^{-1}$ and $\mathrm{yr}^{-1}$, respectively, and scaled for elevation using neutron scaling of Lal (1991). Ages were corrected for sample thickness (max. 3\% correction); no corrections were required for topographic shielding, sample geometry, or snow cover (sites are windswept throughout year with only minor snow accumulation).

${ }^{\mathrm{b}}$ The entire cobble was crushed during sample processing, and its thickness accounted for, so its age is independent of post-depositional movement.

\section{Cosmogenic exposure dating}

We are now able to test the weathering zone concept and the significance of perched erratics on upland surfaces using cosmogenic nuclides. Cosmogenic exposure ages of perched erratics indicate when the uplands were deglaciated, whereas cosmogenic nuclide data from tors test whether the greater degree of rock weathering reflects a much longer and possibly more complex exposure history (cf. Bierman et al., 1999). The advanced weathering of tors implies in situ surface erosion, violating assumptions for calculating surface exposure ages (Gosse and Phillips, 2001). Therefore, we model tor nuclide activities as minimum age limits.

Samples for cosmogenic isotope analysis were collected from tors, erratic boulders and cobbles perched on them, and from erratic boulders on the adjacent Clyde Foreland (Fig. 1). Samples were processed following procedures modified from Kohl and Nishiizumi (1992) at the University of Colorado Cosmogenic Isotope Laboratory and at the University of Vermont following procedures detailed in Bierman and Caffee (2001). ${ }^{10} \mathrm{Be}$ and ${ }^{26} \mathrm{Al}$ measurements were made at the Center for Accelerator Mass Spectrometry at Lawrence Livermore National Laboratory. Ages were calculated using sea-level and high-latitude ${ }^{10} \mathrm{Be}$ and ${ }^{26} \mathrm{Al}$ production rates of 5.1 and 31.1 atoms $\mathrm{g}^{-1} \mathrm{yr}^{-1}$, respectively (Stone, 2000; Gosse and Stone, 2001), with elevation scaling considering only neutrons (Lal, 1991). Ages reported here are the error-weighted means of individual ${ }^{10} \mathrm{Be}$ and ${ }^{26} \mathrm{Al}$ ages for each sample (Table 1$)$.

Tors on each of two nearby summits have minimum model exposure ages of $>67 \pm 7 \mathrm{ka}$ (tor SIV8 at $503 \mathrm{~m}$ asl; Figs 1 and 6; Table 1) and $>60 \pm 4 \mathrm{ka}$ (tor SIV7 at

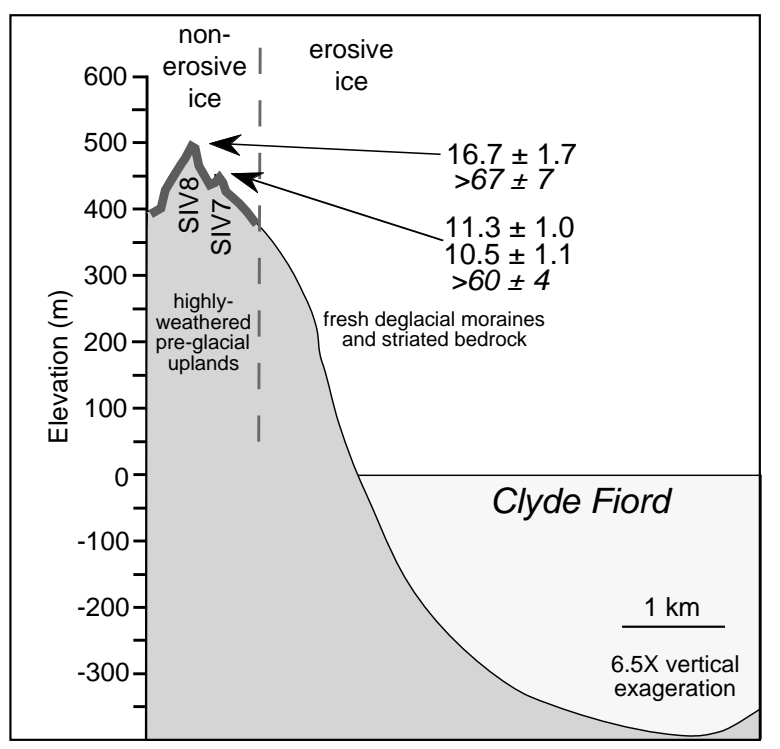

Fig. 6. Topographic transect from the upland tor sites to middle of Clyde Inlet. Fiord depth from Syvitski (unpublished data), and above sea level topography from 1:50000-scale energy, mines, resources Canada topographic map. Proposed boundary between erosive and non-erosive ice is shown. Thick black line indicates where pre-LGM surface is preserved. Plain text numbers are erratic ages; italicized numbers are tor ages.

$465 \mathrm{~m}$ asl; Figs 1 and 6; Table 1). An erratic boulder perched on several cobbles resting on tor SIV8 (Fig. 4) has a cosmogenic exposure age of $16.7 \pm 1.7 \mathrm{ka}$. An erratic boulder (Fig. 5) and a faceted $\sim 5$-cm-thick cobble, both resting on tor SIV7, have ages of $10.5 \pm 1.1$ and $11.3 \pm 1.0 \mathrm{ka}$, respectively. The spread in 
erratic ages may indicate different deglaciation ages for the two summits, or it may reflect nuclide inheritance (cf. Davis et al., 1999). Finally, the ${ }^{26} \mathrm{Al}$ and ${ }^{10} \mathrm{Be}$ concentrations for the two tor samples are consistent $( \pm 1 \sigma)$ with continual exposure, indicating that the uplands adjacent to outer Clyde Inlet were buried by ice for no more $\sim 200000 \mathrm{yr}$ throughout the Quaternary. An alternative explanation of alternating periods of exposure, burial by cold-based ice, and glacial erosion is difficult to resolve with the advanced weathering of the tors.

Four erratic boulders from moraines on the adjacent Clyde Foreland (Fig. 1) yield an average cosmogenic exposure age of $17.8 \pm 0.7 \mathrm{ka}$ (Table 1). The samples were collected from stable boulders with exposed diameters $>3 \mathrm{~m}$ on the outermost Patricia Bay moraine. These ages indicate that ice reached the mouth of Clyde Inlet during the LGM (Briner and Miller, 2002).

\section{Discussion}

Although our dataset is relatively small it is robust. Erratic blocks perched on tors could have only been emplaced by the LIS because the source material available for transportation by upland ice is weathered blockfield boulders, not the subrounded, relatively fresh erratics that are observed. The erratics rest directly on windswept, stable tor surfaces, hence have experienced minimal post-depositional shielding or movement. Consequently, their ages date deglaciation of the upland.

Our data suggest that LGM ice was more extensive than previous field-based reconstructions for the region (Løken, 1966; Miller et al., 1977; Dyke et al., 2002; Miller et al., 2002). Dates on high-elevation erratics within a few kilometers of the fiord mouth, combined with LGM cosmogenic exposure ages from low-elevation samples collected from the Clyde Foreland, indicate that relatively thick Laurentide ice terminated on the continental shelf during the LGM.

Our results indicate that cold-based, non-erosive Laurentide ice covered the uplands immediately adjacent to Clyde Inlet during the LGM. Melt-water channels on the plateau near the sampled tors further support the presence of cold-based ice. At lower elevations, striated bedrock indicates that erosive, warm-based ice occupied the fiord. Accommodating erosive ice in the fiords and non-erosive ice on adjacent uplands and coastal forelands requires a sharp $(<1 \mathrm{~km}$ wide) boundary between cold-based and warm-based zones (Fig. 6). Hence, we suggest that an ice stream occupied Clyde Inlet during the LGM.

The preservation of ancient landscapes beneath ice sheet centers is widely recognized (e.g., Dyke, 1993; Kleman, 1994; Kleman and Stroeven, 1997; Kleman et al., 1999; Dredge, 2000; Fabel et al., 2002; Hättestrand et al., 2002; Stroeven et al., 2002). Some of these preserved landscapes are probably pre-Quaternary, indicating that they have been covered by coldbased ice during repeated glacial cycles (e.g., Kleman, 1994; Fabel et al., 2002; Stroeven et al., 2002). The preservation of pre-glacial upland surfaces close to the former LIS margin is only recently gaining recognition. Bierman et al. (2001) report an LGM cosmogenic exposure age for an erratic adjacent to a pre-LGMaged tor along on southern Baffin Island, and suggest that cold-based ice existed there. Similarly, research in the Torngat Mountains of Labrador has revealed evidence for the preservation of weathered terrain within LGM ice limits (e.g., Gosse and Willenbring, 2002).

Our finding of cold-based, non-erosive Laurentide ice on the upland plateaus in outer Clyde Inlet complements the work of Bierman et al. (2001) and Gosse and Willenbring (2002), and suggests that an ice-stream mode of glaciation dominated fiord landscapes on Baffin Island. Ice streams are currently thought to have occupied Hudson Strait and Cumberland Sound on southern Baffin Island (Andrews et al., 1985; Kaplan et al., 2001), but have only been theoretically postulated for fiords of northeastern Baffin Island (e.g., Hughes, 1998). Our reconstruction is consistent with the selective linear erosion model of LIS dynamics along northeastern Baffin Island (Sugden, 1978), which places warm-based erosive ice in the fiords, and cold-based, non-erosive ice over the highlands. In addition, our model is consistent with a recent "just right" model of ice dynamics that invokes highly variable basal thermal regimes between fiords and inter-fiord plateaus (Miller et al., 2002). We speculate that ice was cold-based on uplands because it was relatively thin and flowed over crystalline bedrock, whereas in fiords, ice was thick, constrained, and flowed over water-saturated unconsolidated sediments. Additionally, Clyde Inlet, like most fiords along northeastern Baffin Island, extends through the coastal mountain range into the interior of the ice sheet (Fig. 1). This geometry provides highly convergent topography in the ice stream onset zone (Stokes and Clark, 2001).

\section{Conclusions}

Cosmogenic nuclide measurements demonstrate that upland blockfields and tors in northeastern Baffin Island were glacierized during the LGM. Despite advanced weathering characteristics, they cannot be used to argue for the absence of LGM ice (refugia). The contrast in basal thermal regimes across short distances supports the concept of an ice stream in Clyde Inlet during the LGM. We propose that this style of glaciation dominated the fiord coastlines of Baffin Island where 
the topography and glacial geology are similar to the Clyde Region. Ice-stream-dominated ice sheet margins are dynamic and unstable, and consequently, the northeastern margin of the LIS was likely sensitive to abrupt reorganization that may include the coupling of ice sheets, ocean circulation and climate that produce Heinrich and $\mathrm{D} / \mathrm{O}$ events.

\section{Acknowledgements}

We thank Yarrow Axford, John Gosse, Jon Landvik, and an anonymous reviewer for helpful comments on the manuscript, and Robert Austin, Brian Clarke, Daniel Goldstein, and Michael Robinson for field and laboratory assistance. Robert Finkel assisted with AMS analyses at Lawrence Livermore National laboratory. We acknowledge with appreciation the permission to access the field area from the Inuit of Clyde River and the assistance of the Nunavut Research Institute. This research was supported by US National Science Foundation grants OPP-0004466 and OPP-0138010 to GHM and PTD, and by grants from the Geological Society of America, the University of Colorado, and the American Alpine Club to JPB.

\section{References}

Alley, R.B., MacAyeal, D.R., 1994. Ice-rafted debris associated with binge/purge oscillations of the Laurentide Ice Sheet. Paleoceanography $9,503-511$.

Andrews, J.T., Stravers, J.A., Miller, G.H., 1985. In: Woldenburg, M.J. (Ed.), Patterns of Glacial Erosion and Deposition around Cumberland Sound, Frobisher Bay and Hudson Strait, and the Location of Ice Streams in the Eastern Canadian Arctic. Models in Geomorphology. Allen \& Unwin, London.

Bierman, P.R., Caffee, M., 2001. Slow rates of rock surface erosion and sediment production across the Namib Desert and escarpment, Southern Africa. American Journal of Science 301, 326-358.

Bierman, P.R., Marsella, K.A., Davis, P.T., Caffee, M.W., 2001. Response to Discussion by Wolfe, et al., on Bierman, et al., Geomorphology 27 (1999) 25-39. Geomorphology 39, 255-260.

Bierman, P.R., Marsella, K.A., Patterson, C., Davis, P.T., Caffee, M., 1999. Mid-Pleistocene cosmogenic minimum-age limits for preWisconsin glacial surfaces in southwestern Minnesota and southern Baffin Island: a multiple nuclide approach. Geomorphology 27, 25-39.

Boyer, S.J., Pheasant, D.R., 1974. Delimitation of weathering zones in the fiord area of eastern Baffin Island, Canada. Geological Society of America Bulletin 85, 805-810.

Briner, J.P., Miller, G.H., 2002. The hunt for the LGM, northeastern Baffin Island: on the trail of elusive cold-based ice. 32nd Arctic Workshop Program and Abstracts, 33-35.

Brook, E.J., Nesje, A., Lehman, S.J., Raisbeck, G.M., Yiou, F., 1996. Cosmogenic nuclide exposure ages along a vertical transect in western Norway: implications for the height of the Fennoscandian ice sheet. Geology 24, 207-210.

Clark, P.U., 1994. Unstable behavior of the Laurentide ice sheet over deforming sediment and its implications for climate change. Quaternary Research 41, 19-25.
Dahl, E., 1955. Biogeographic and geological indications of unglaciated areas in Scandinavia during the glacial ages. Geological Society of American Bulletin 66, 1499-1519.

Dahl, R., 1966. Block fields, weathering pits and tor-like forms in the Narvik Mountains, Nordland, Norway. Geografiska Annaler 48A, 55-85.

Davis, P.T., Bierman, P.R., Marsella, K.A., Caffee, M.W., Southon, J.R., 1999. Cosmogenic analysis of glacial terrains in the eastern Canadian arctic: a test for inherited nuclides and the effectiveness of glacial erosion. Annals of Glaciology 28, 181-188.

Denton, G., Hughes, T. (Eds.), 1981. The Last Great Ice Sheets. Wiley, New York, 484pp.

Dredge, L.A., 2000. Age and origin of upland block fields on Melville Peninsula, eastern Canadian Arctic. Geografiska Annaler 82A, 443-454.

Dyke, A.S., 1993. Landscapes of cold-centred Late Wisconsinan ice caps, Arctic Canada. Progress in Physical Geography 17, 223-247.

Dyke, A.S., Andrews, J.T., Clark, P.U., England, J.H., Miller, G.H., Shaw, J., Veillette, J.J., 2002. The Laurentide and Innuitian ice sheets during the Last Glacial Maximum. Quaternary Science Reviews 21, 9-31.

Fabel, D., Stroeven, A.P., Harbor, J., Kleman, J., Elmore, D., Fink, D., 2002. Landscape preservation under Fennoscandian ice sheets determined from in situ produced ${ }^{10} \mathrm{Be}$ and ${ }^{26} \mathrm{Al}$. Earth and Planetary Science Letters 201, 397-406.

Fernald, M.L., 1925. Persistence of plants in unglaciated areas of boreal North America. Memoirs of the American Academy of Science 15, 237-242.

Gosse, J.C., Phillips, F.M., 2001. Terrestrial in situ cosmogenic nuclides: theory and application. Quaternary Science Reviews 20, $1475-1560$.

Gosse, J.C., Stone, J.O., 2001. Terrestrial cosmogenic nuclide methods passing milestones toward paleo-altimetry. Eos (Transactions, American Geophysical Union) 82, 82, 86, 89.

Gosse, J.C., Willenbring, J., 2002. Glacier erosion factory: using ${ }^{26} \mathrm{Al} /{ }^{10} \mathrm{Be}$, soils, and geomorphology to study relief development. Goldschmidt Conference Abstracts, A287.

Hättestrand, C., Stroeven, A.P., 2002. A relict landscape in the center of Fennoscandian glaciation: geomorphological evidence of minimal Quaternary glacial erosion. Geomorphology 44, $127-143$.

Hughes, T.J., 1998. Ice Sheets. Oxford University Press, New York.

Ives, J.D., 1966. Block fields, associated weathering forms on mountain tops and the Nunatak hypothesis. Geografiska Annaler $48 \mathrm{~A}, 220-223$.

Ives, J.D., 1975. Delimitation of surface weathering zones in eastern Baffin Island, Northern Labrador and Arctic Norway: a discussion. Geological Society of America Bulletin 86, 1096-1100.

Ives, J.D., 1978. The maximum extent of the Laurentide ice sheet along the east coast of North America during the last glaciation. Arctic 31, 24-53.

Kaplan, M.R., Miller, G.H., Steig, E.J., 2001. Low-gradient outlet glacies (ice streams?) drained the northeastern Laurentide ice sheet. Geology 29, 343-346.

Kleman, J., 1994. Preservation of landforms under ice sheets and ice caps. Geomorphology 9, 19-32.

Kleman, J., Hättestrand, C., 1999. Frozen-bed Fennoscandian and Laurentide ice sheets during the Last Glacial Maximum. Nature 402, 63-66.

Kleman, J., Stroeven, A.P., 1997. Preglacial surface remnants and Quaternary glacial regimes in northwestern Sweden. Geomorphology 19, 35-54.

Kohl, C.P., Nishiizumi, K., 1992. Chemical isolation of quartz for measurement of in-situ-produced cosmogenic nuclides. Geochimica et Cosmochimica Acta 56, 3583-3587. 
Lal, D., 1991. Cosmic ray labeling of erosion surfaces: in-situ nuclide production rates and erosion models. Earth and Planetary Science Letters 104, 424-439.

Landvik, J.Y., 1994. The last glaciation of Germania land and adjacent areas, northeast Greenland. Journal of Quaternary Science 9, $81-92$.

Linton, D.L., 1950. Unglaciated enclaves in glaciated regions. Journal of Glaciology 1, 451-453.

Løken, O.H., 1966. Baffin Island refugia older than 54000 years. Science 153, 1378-1380.

Miller, G.H., Andrews, J.T., Short, S.K., 1977. The last interglacialglacial cycle, Clyde foreland, Baffin Island, N.W.T: stratigraphy, biostratigraphy, and chronology. Canadian Journal of Earth Sciences 14, 2824-2857.

Miller, G.H., Wolfe, A.P., Steig, E.J., Sauer, P.E., Kaplan, M.R., Briner, J.P., 2002. The Goldilocks dilemma: big ice, little ice, or just right ice in the eastern Canadian Arctic. Quaternary Science Reviews 21, 33-48.
Nesje, A., Dahl, S.O., 1990. Autochthonous block fields in southern Norway: implications for the geometry, thickness, and isostatic loading of the late Weichselian Scandinavian ice sheet. Journal of Quaternary Science 5, 225-234.

Peltier, R., 1994. Ice age paleotopography. Science 265, 195-201.

Stokes, C.R., Clark, C.D., 2001. Paleo-ice streams. Quaternary Science Reviews 20, 1437-1457.

Stone, J.O., 2000. Air pressure and cosmogenic isotope production. Journal of Geophysical Research 105, 23753-23759.

Stroeven, A.P., Fabel, D., Hättestrand, C., Harbor, J., 2002. A relict landscape in the center of Fennoscandian glaciation: cosmogenic radionuclide evidence of tors preserved through multiple glacial cycles. Geomorphology 44, 145-154.

Sugden, D.E., 1978. Glacial erosion by the Laurentide ice sheet. Journal of Glaciology 83, 367-391.

Sugden, D.E., Watts, S.H., 1977. Tors, felsenmeer, and glaciation in northern Cumberland Peninsula, Baffin Island. Canadian Journal of Earth Sciences 14, 2817-2823. 